\title{
Pengembangan media pembelajaran matematika berbasis macromedia flash pada materi koordinat kartesius kelas VIII SMP
}

\author{
Muhammad Agung Alghifaari', Nani Kurniati², \\ Wahidaturrahmi ${ }^{2}$
}

\author{
${ }^{1}$ Mahasiswa Pendidikan Matematika, FKIP, Universitas Mataram, Mataram \\ 2 Pendidikan Matematika, FKIP, Universitas Mataram, Mataram
}

alghifaari98@yahoo.com

Diterima:14-12-2021 ; Direvisi:30-12-2021; Dipublikasi: 30-12-2021

\begin{abstract}
The purpose of this research are to develop macromedia flash-based mathematics learning media for cartesian coordinate material for class VIII SMP. Macromedia flash-based learning media is an audio-visual media presented in the form of software consisting of basic competencies, learning objectives, materials and quizzes. This development aims to overcome the weaknesses in the learning process that have occurred due to the lack of use of media in classroom, besides that it can also assist students in learning the concept of cartesian coordinates, especially in visualizing the objects in the material. The research methodology used in developing this learning media is 4D (Define, Design, Developement, Dissemination). Data collection techniques using interview guidelines and questionnaires. The result of this research is a software product of learning media for cartesian coordinates based on macromedia flash in the CD form. The product has been declared valid with good criteria by 4 validators. Based on the limited trial, it is known that the response of class VIII students of SMP that use the macromedia flash-based learning media cartesian coordinate is good.
\end{abstract}

Keywords: Developing media, Macromedia Flash, Cartesian Coordinate.

\begin{abstract}
Abstrak
Tujuan penelitian ini adalah untuk mengembangkan media pembelajaran matematika berbasis Macromedia Flash materi koordinat kartesius kelas VIII SMP. Media pembelajaran berbasis macromedia flash merupakan media audio visual yang disajikan dalam bentuk software yang terdiri atas KD, tujuan pembelajaran, materi dan quiz. Pengembangan ini bertujuan untuk mengatasi kelemahan-kelemahan dalam proses pembelajaran yang selama ini terjadi karena guru kurang memanfaatkan media dalam pembelajaran dalam kelas, selain itu juga dapat membantu siswa dalam mempelajari konsep koordinat kartesius khususnya dalam memvisualisasikan objek objek yang ada pada materi tersebut. Metodologi penelitian yang digunakan dalam mengembangkan media pembelajaran ini adalah 4D (Define, Design, Developement, Dissemination). Teknik pengumpulan data menggunakan pedoman wawancara dan angket. Hasil penelitian adalah berupa produk software media pembelajaran materi koordinat kartesius berbasis macromedia flash yang berbentuk CD. Produk telah dinyatakan valid dengan kriteria baik oleh 4 orang validator. Berdasarkan uji coba terbatas diketahui bahwa respon siswa kelas VIII SMP terhadap penggunaan media pembelajaran berbasis macromedia flash materi koordinat kartesius adalah berkategori baik
\end{abstract}

Kata Kunci: Pengembangan Media, Macromedia Flash, Koordinat Kartesius. 


\section{PENDAHULUAN}

Pendidikan adalah usaha sadar dan terencana untuk mengembangkan potensi diri siswa sehingga bermanfaat bagi dirinya, masyarakat, bangsa dan Negara (Depdiknas, 2003). Pendidikan bertujuan untuk meningkatkan kecerdasan, pengetahuan, kepribadian, akhlak mulia, serta keterampilan siswa untuk hidup mandiri dan mengikuti pendidikan pada tingkat lebih lanjut (Depdiknas, 2006). Pembelajaran merupakan proses dari pendidikan, dari sanalah lingkup kecil secara formal yang menetukan dunia pendidikan berjalan baik atau tidak. Pembelajaran merupakan suatu proses menciptakan kondisi kondusif agar terjadi interaksi komunikasi belajar mengajar antara guru, siswa, dan komponen pembelajaran lainnya untuk mencapai tujuan pembelajaran (Rusman, 2012).

Perkembangan teknologi informasi dan komunikasi melaju begitu cepat dibandingkan perkiraan semula, kemajuan tersebut merambat ke semua sektor kehidupan salah satunya sektor pendidikan (Prawiradilaga, 2013). Dengan adanya teknologi dapat meningkatkan kualitas belajar siswa. Selain itu juga kemajuan ilmu pengetahuan dan teknologi telah berpengaruh terhadap penggunaan alat-alat bantu mengajar di sekolah (Muhson, 2010). Pembelajaran di sekolah harus disesuaikan dengan perkembangan teknologi informasi (Sanaky, 2009). Hal ini mengindikasikan bahwa penggunaan teknologi informasi dalam proses pembelajaran di kelas, sudah menjadi suatu kebutuhan sekaligus tuntutan di zaman ini. Di SMP terdapat sarana pendukung pembelajaran yakni laboratorium komputer yang lengkap, namun belum dimanfaatkan dengan maksimal. Pemanfaatan teknologi dalam pembelajaran dapat berupa penggunaan media pembelajaran berbasis komputer. Hasil penelitian Masykur (Masykur, 2017) menunjukkan bahwa pembelajaran matematika menggunakan media pembelajaran berbasis komputer sangat menarik bagi siswa dan dapat membantu siswa dalam memahami materi.

Media pembelajaran berbasis komputer dapat dikembangkan dengan bantuan aplikasi macromedia flash. Macromedia flash (Fanani, 2007) menggunakan bahasa pemrograman yakni ActionScript yang dapat digunakan membuat animasi atau interaksi berbasis komputer. Macromedia flash memiliki kemampuan dan fitur-fitur lengkap sehingga dapat digunakan untuk membuat berbagai macam aplikasi seperti animasi web kartun, multimedia interaktif, sampai aplikasi untuk ponsel (Andrisa, 2007). Hal tersebut sesuai dengan penelitian Hadiprayitno yang mengembangkan media pembelajaran berbasis macromedia flash. Penelitiannya menghasilkan media pembelajaran yang penyajiannya mudah dipahami, menarik dan tidak monoton (Hadipryitno, 2012).

Salah satu materi matematika yang diajarkan pada kelas VIII adalah koordinat kartesius. Materi tersebut memiliki kompetensi dasar yakni menjelaskan kedudukan titik di dalam bidang koordinat kartesius yang dihubungkan dengan masalah kontekstual dan menyelesaikan masalah yang berkaitan dengan kedudukan titik dalam bidang koordinat kartesius. Menilik hasil ulangan pada materi koordinat kartesius 
siswa kelas VIII di SMP tahun ajaran 2019/2020, terdapat cukup banyak siswa yang tidak memenuhi nilai KKM. Berdasarkan hasil wawancara dengan guru mata pelajaran matematika di SMP, siswa memliki masalah dalam memahami konsep garis sumbu $\mathrm{X}$ dan $\mathrm{Y}$, belum mampu menggambar grafik dengan benar dan sering keliru dalam penulisan koordinat. Lebih lanjut lagi menurut keterangan guru, didapatkan informasi bahwa dalam menyampaikan materi koordinat kartesius beliau hanya menggunakan media pembelajaran berupa papan tulis. Alasannya, guru belum mampu mengembangkan media yang baik. Selain itu ketersediaan media pembelajaran di internet yang bersifat interaktif masih tergolong minim. Ini mengindikasikan bahwa perlu adanya inovasi dalam pembelajaran matematika materi koordinat kartesius. Hakekat pembelajaran sesungguhnya mengacu kepada usaha membuat siswa percaya bahwa belajar memberikan kesempatan kepada mereka untuk lebih aktif dalam berpikir dan berjuang menemukan ide-ide dalam pembelajaran (Turmuzi, M. 2017). Strategi belajar yang digunakan oleh guru dan cara penyajian bahan pembelajaran dapat berpengaruh terhadap tingkat ketertarikan siswa dalam suatu pembelajaran.

Atas dasar hal-hal tersebut, peneliti merasa perlu adanya penelitian yang mengembangkan media pembelajaran yang dapat membantu siswa dalam pembelajaran materi koordinat kartesius. Peneliti mengangkat judul Pengembangan Media Pembelajaran Matematika Berbasis Macromedia Flash Materi Koordinat Kartesius Siswa Kelas VIII SMP.

\section{METODE PELAKSANAAN}

Jenis penelitian ini adalah penelitian pengembangan yang bertujuan untuk menghasilkan produk berupa media pembelajaran matematika berbasis macromedia flash pada materi koordinat kartesius kelas VIII. Pada penelitian ini model pengembangan yang digunakan adalah model pengembangan 4D yang terdiri dari 4 tahapan (Sutarti, 2017). yaitu define, design, develop, dan disseninate. Dalam mengembangakan media pembelajaran harus memperhatikan prinsip-prinsip berikut (Jalinus, N, 2016). yaitu dapat dirumuskan dalam satu kata ACTION, yaitu akronim dari (1) Access (kemudahan dalam mengakses medianya), (2) Cost (biaya yang digunakan terjangkau oleh siswa), (3) Technology (teknologinya harus sesuai dengan kemampuan siswa), (4) Interactivity (membuat siswa interaktif), (5) Organization (dukungan organisasi atau sekolah sebagai penyedia fasilitas), dan Novelty (kebaruan media agar sesuai dengan perkembangan zaman).

Salah satu kriteria yang harus dipenuhi oleh media pembelajaran yang layak adalah media tersebut harus valid. Kevalidan media pembelajaran ini dinilai menggunakan validitas konstruk dengan menggunakan pendapat para ahli dan respon siswa sebagai pengguna (Purwanto, 2011). Penilaian kevalidan media berbasis macromedia flash dilakukan menggunakan instrumen angket ahli dan respon siswa (Sugiyono, 2017). Lembar angket validasi tersebut disusun berdasarkan kriteria kelayakan media pembelajaran menurut Mc Alpine (Chaeruman, 2015). Terdapat 3 aspek yang menjadi acuan media pembelajaran tersebut baik atau tidak. (1) Aspek materi (content), (2) 
Aspek media \& komunikasi pembelajaran, dan (3) Aspek daya implementasi \& respon pengguna. Aspek pertama akan dinilai oleh 2 ahli materi, aspek kedua akan dinilai oleh 2 ahli media dan aspek ketiga dinilai oleh siswa kelas VIII sebagai pengguna.

Data yang diperoleh dari angket validasi ahli dan respon siswa berupa data kualitatif dan kuantitatif. Data kualitatif merupakan uraian penilaian yang dijadikan perbaikan (revisi) dari para ahli dan siswa tentang media yang dikembangkan, sedangkan data kuantitatif berupa skor diolah menggunakan analisis deskriptif, kemudian dikonversi menggunakan pedoman konversi (Gunawan, 2015).

Tabel 3.1 Panduan konversi data kuantitatif instrumen ahli dan respon siswa

\begin{tabular}{ccc}
\hline Rumus Kriteria & Rentang skor & Kualifikasi \\
$X>\left(M_{i}+1,8 S D_{i}\right)$ & $\mathrm{X}>4,2$ & Sangat Baik \\
$\left(M_{i}+0,6 S D_{i}\right)<X \leq\left(M_{i}+1,8 S D_{i}\right)$ & $3,4<\mathrm{X} \leq 4,2$ & Baik \\
$\left(M_{i}-0,6 S D_{i}\right)<X \leq\left(M_{i}+0,6 S D_{i}\right)$ & $2,6<\mathrm{X} \leq 3,4$ & Cukup \\
$\left(M_{i}-1,8 S D_{i}\right)<X \leq\left(M_{i}-0,6 S D_{i}\right)$ & $1,8<\mathrm{X} \leq 2,6$ & Kurang \\
$X<\left(M_{i}-1,8 S D_{i}\right)$ & $\mathrm{X} \leq 1,8$ & Sangat Kurang \\
\hline
\end{tabular}

Keterangan :

$X$ : Skor yang didapat

$M_{i}($ Rata - rata skor ideal $)=1 / 2($ skor maksimal + skor minimum $)$

$S D_{i}($ Simpangan baku ideal $)=1 / 6($ skor maksimal - skor minimal $)$

\section{HASIL DAN PEMBAHASAN}

Model pengembangan 4-D memiliki 4 tahapan. Berikut adalah penjelasan tahapan pembuatan media pembelajaran macromedia flash materi koordinat kartesius.

\subsection{Tahap pendefinisian (Define)}

Tahap pendefinisian dilakukan untuk menentukan kebutuhan-kebutuhan di dalam proses pembelajaran serta mengumpulkan berbagai informasi yang berkaitan dengan produk yang akan dikembangkan seperti KD dan tujuan pembelajaran

Tabel 3.1 KD dan Indikator

\begin{tabular}{|c|c|c|}
\hline & $\mathrm{KD}$ & Indikator \\
\hline 3.2 & $\begin{array}{l}\text { Menjelaskan kedudukan titik dalam } \\
\text { bidang koordinat Kartesius yang } \\
\text { dihubungkan dengan masalah } \\
\text { kontekstual }\end{array}$ & $\begin{array}{l}\text { 3.2.1. Mengidentifikasi konsep diagram } \\
\text { kartesius } \\
\text { 3.2.2. } \\
\text { Mengidentifikasi pembagian kuadran } \\
\text { bidang kartesius } \\
\text { 3.2.3. } \text { Mendeskripsikan langkah-langkah } \\
\text { menggambar titik pada koordinat } \\
\text { kartesius } \\
\text { 3.2.4. } \text { Mengidentifikasi pengertian jarak } \\
\text { antara dua titik pada bidang kartesius } \\
\text { 3.2.5. } \text { Mendeskripsikan langkah-langkah } \\
\text { menentukan jarak dua buah titik dalam } \\
\text { bidang kartesius } \\
\text { 3.2.6. Menetukan jarak antar dua titik }\end{array}$ \\
\hline
\end{tabular}


4.2 Menyelesaikan masalah yang berkaitan dengan

kedudukan titik dalam bidang koordinat

Kartesius
4.2.1. Menyajikan hasil pembelajaran tentang koordinat Kartesius

4.2.2. Menyelesaikan masalah tentang bidang koordinat Kartesius

Tabel 3.2 Tujuan Pembelajaran

\begin{tabular}{cl}
\hline NO & Tujuan Pembelajaran \\
\hline 1 & Siswa dapat menentukan posisi titik terhadap sumbu x dan sumbu y. \\
2 & Siswa dapat menentukan posisi titik terhadap titik asal $(0,0)$ dan titik tertentu $(\mathrm{a}, \mathrm{b})$. \\
3 & Siswa dapat menentukan posisi garis yang sejajar dengan sumbu x dan sumbu y. \\
4 & Siswa dapat menentukan posisi garis yang berpotongan dengan sumbu x dan sumbu y \\
5 & Siswa dapat menentukan posisi garis yang tegak lurus dengan sumbu x dan sumbu y \\
\hline
\end{tabular}

\subsection{Tahap Perancangan (Design)}

Desain materi pada media pembelajaran ini dibuat berdasarkan tahapan define. Pada tahap ini peneliti menggunakan flowchart untuk mengambarkan aliran dari satu scene ke scene yang lain dan storyboard untuk menggambarkan deskripsi tiap scene.

\subsection{Tahap Pengembangan (Develop)}

Pada tahap ini dilakukan beberapa proses yaitu pembuatan media pembelajaran sesuai dengan flowchart dan storyboard, proses validasi media yang telah jadi, dan uji coba terbatas.

\section{A. Pembuatan produk}

Pembuatan media pembelajaran dari awal sampai jadi. Adapun tampilan media pembelajaran sebagai berikut.

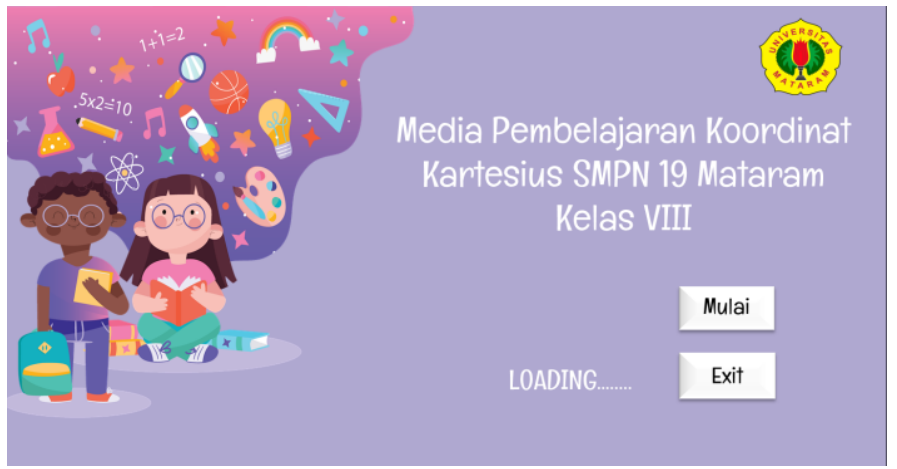

Gambar 3.1 Animasi Loading dan Tombol Mulai 


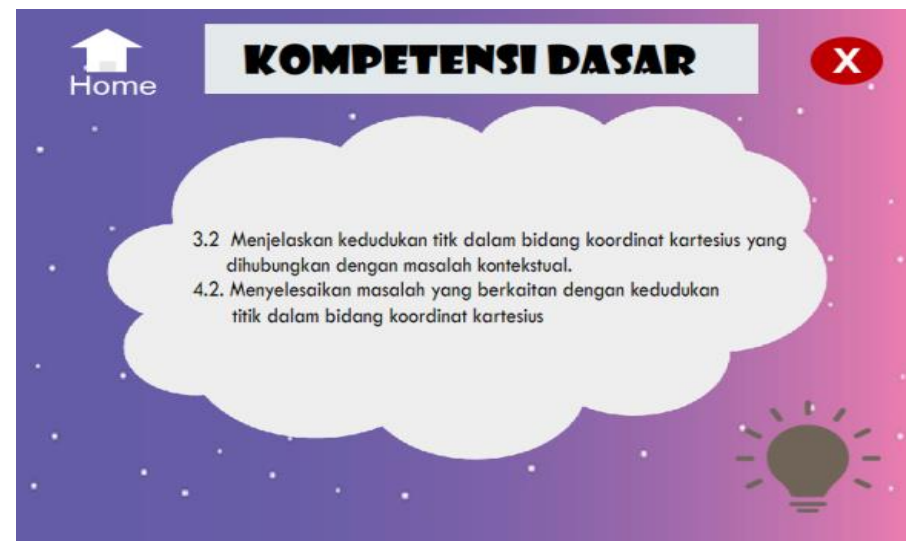

Gambar 3.2 Tampilan Halaman KD

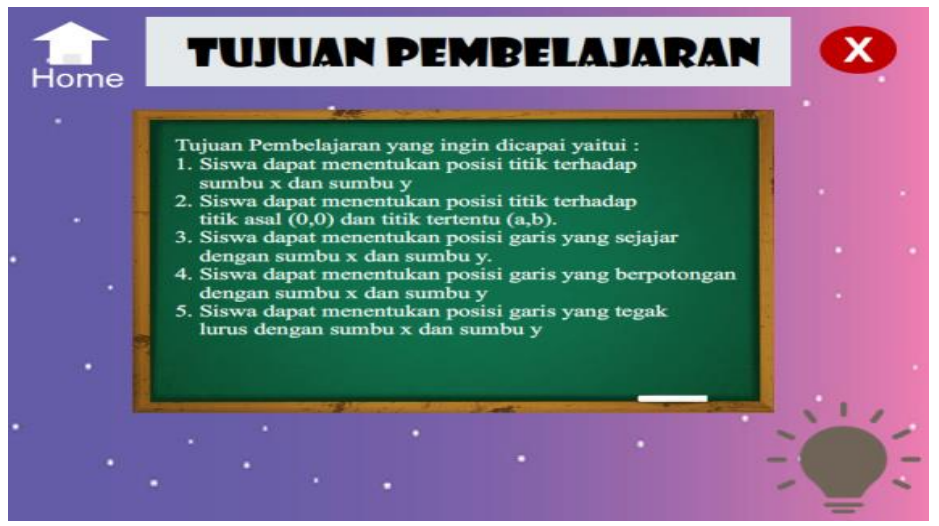

Gambar 3.3 Halaman Tujuan Pembelajaran

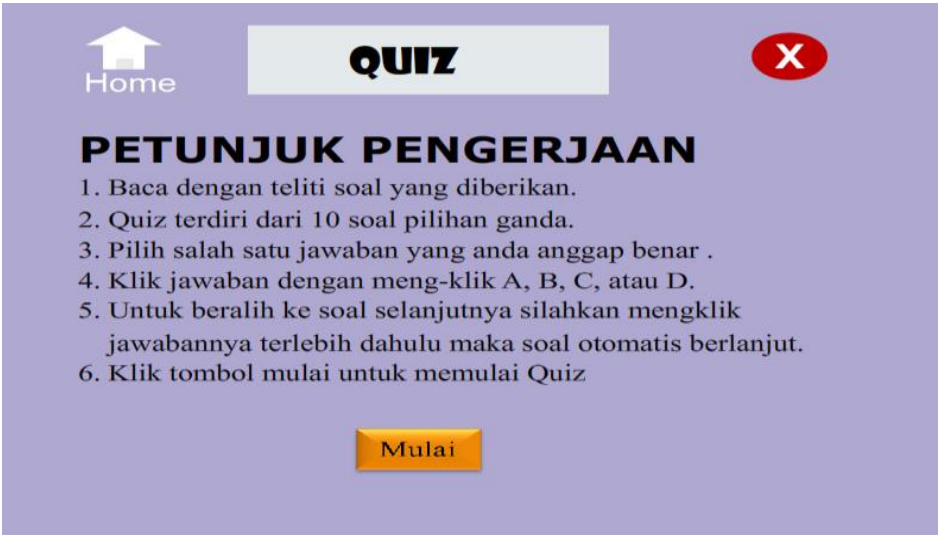

Gambar 3.4 Halaman Quiz

B. Validasi ahli

Validasi materi dilakukan oleh dua orang ahli Validasi ini bertujuan untuk mengetahui kualitas materi (content) yang ada di dalam media pembelajaran yang dibuat. Hasil penilaian dari masing-masing indikator tersebut dapat dilihat pada tabel di bawah ini. 
Tabel 3.3 Penilaian Materi Berdasarkan Indikator Kisi-Kisi Angket Ahli Materi

\begin{tabular}{clcccc}
\hline No & \multicolumn{1}{c}{ Indikator penialaian } & \multicolumn{2}{c}{ Validator } & Rata & Kualifikasi \\
& & 1 & 2 & rata & \\
\hline 1 & Kebenaran isi materi dan bebas dari & 4,2 & 4,4 & 4,3 & Sangat baik \\
& $\begin{array}{l}\text { kesalahan konsep } \\
2\end{array}$ & & & & \\
3 & Kekinian dan kebaharuan materi & 4,3 & 4,6 & 4,5 & Sangat baik \\
$\quad$ Kecakupan dan kecukupan materi & 4,5 & 4,5 & 4,5 & Sangat baik \\
$\quad$ Rata-rata keseluruhan & & & 4,4 & Sangat baik \\
\hline
\end{tabular}

Validasi media dilakukan oleh dua orang Validasi ini bertujuan untuk mengetahui kualitas dari software media berbasis macromedia flash yang dibuat. Hasil penilaian dari masing-masing indikator dapat dilihat pada tabel berikut.

Tabel 3.4 Penilaian Media Berdasarkan Indikator Kisi-Kisi Angket Ahli Media

\begin{tabular}{|c|c|c|c|c|c|}
\hline \multirow[t]{2}{*}{ No } & \multirow[t]{2}{*}{ Indikator penialaian } & \multicolumn{2}{|c|}{ Validator } & \multirow[t]{2}{*}{ Rata rata } & \multirow[t]{2}{*}{ Kualifikasi } \\
\hline & & 1 & 2 & & \\
\hline 1 & $\begin{array}{llr}\text { Kesesuaian dan } & \text { kualitas } \\
\text { pemanfaatan grafis dan visual } \\
\text { (diagram, tabel, bagan) } & \text { dengan } \\
\text { tujuan, isi, materi, dan karakteristik }\end{array}$ & 4,0 & 4,0 & 4,0 & Baik \\
\hline 2 & $\begin{array}{l}\text { Ketepatan penggunaan bahasa } \\
\text { komunikasi sesuai dengan tujuan, isi } \\
\text { materi dan karakteristik audiens } \\
\text { (siswa) terkait }\end{array}$ & 4,7 & 4,7 & 4,7 & Baik \\
\hline 3 & $\begin{array}{lll}\text { Tingkat } & \text { interaktifitas } & \text { dan } \\
\text { kemudahan } & & \\
\text { Navigasi } & \end{array}$ & 4,5 & 4,0 & 4,2 & Baik \\
\hline 4 & $\begin{array}{l}\text { Kemenarikan pengemasan media } \\
\text { secara keseluruhan (typologi, warna, } \\
\text { ilustrasi, icon, tata letak, dll) }\end{array}$ & 4,0 & 4,0 & 4,0 & Baik \\
\hline & Rata-rata keseluruhan & & & & Baik \\
\hline
\end{tabular}

C. Uji coba terbatas

Untuk mengetahui respon siswa dilakukan uji coba terbatas terhadap siswa kelas VIII SMPN 19 Mataram. Siswa yang terlibat dalam uji coba terbatas adalah 9 orang yang terbagi dalam 3 kategori yaitu siswa berkemampuan tinggi, sedang dan rendah. Siswa berkemampuan rendah yaitu S1,S2, S3. Siswa berkemampuan sedang yaitu S4, S5, S6. Siswa berkemampuan tinggi yaitu S7,S8, S9. Adapun hasil penilaian dari masing-masing kategori siswa dapat dilihat pada tabel di bawah ini. 
Tabel 3.5 Hasil Uji Coba Terbatas 9 siswa

\begin{tabular}{|c|c|c|c|c|c|c|}
\hline \multirow[t]{2}{*}{ No } & \multirow[t]{2}{*}{ Indikator penialaian } & \multicolumn{3}{|c|}{$\begin{array}{l}\text { Rata- rata berdasarkan } \\
\text { tingkat kemampuan siswa }\end{array}$} & \multirow{2}{*}{$\begin{array}{l}\text { Rata } \\
\text { rata per } \\
\text { indikator }\end{array}$} & \multirow[t]{2}{*}{ Kualifikasi } \\
\hline & & Rendah & Sedang & Tinggi & & \\
\hline 1 & $\begin{array}{l}\text { Kemudahan dan kenyamanan } \\
\text { penggunaan media }\end{array}$ & 4 & 4 & 4 & 4,0 & Baik \\
\hline 2 & $\begin{array}{l}\text { Tingkat minat dan motivasi } \\
\text { siswa ketika digunakan dalam } \\
\text { pembelajaran baik individu } \\
\text { maupun di dalam kelas dan di } \\
\text { luar kelas }\end{array}$ & 4 & 4,2 & 4,6 & 4,2 & Baik \\
\hline 3 & $\begin{array}{l}\text { Tingkat kemungkinan } \\
\text { mendorong kemampuan siswa } \\
\text { berpikir kritis dan mandiri } \\
\text { dalam memecahkan masalah }\end{array}$ & 3,8 & 4,3 & 4,3 & 4,1 & Baik \\
\hline 4 & $\begin{array}{l}\text { Kemungkinan } \\
\text { digunakan untuk belajar } \\
\text { individu oleh siswa dan atau } \\
\text { alat bantu mengajar bagi guru }\end{array}$ & 3,5 & 4,1 & 3,6 & 3,8 & Baik \\
\hline & Rata-rata keseluruhan & & & 0 & & Baik \\
\hline
\end{tabular}

\subsection{Tahap Penyebaran (Disseminate)}

Proses yang dilakukan dalam tahap produksi adalah menyimpan media pembelajaran ke media penyimpanan yang berupa Compact Disk (CD). Setelah dilakukan penyimpanan, media pembelajaran didistribusikan ke guru mata pelajaran matematika kelas VIII SMPN 19 Mataram untuk dijadikan sebagai alat bantu mengajar dalam proses pembelajaran.

Media pembelajaran berbasis macromedia flash untuk materi koordinat kartesius kelas VIII di SMPN 19 Mataram ini merupakan media yang disajikan dalam bentuk software. Media ini tergolong sebagai media berbasis komputer yang dapat dioperasikan dengan komputer/laptop. Berdasarkan penelitian Arsid (Arsid, 2020). penggunaan media berbasis komputer dalam dapat meningkatkan perhatian siswa terhadap materi yang diajarkan dan berpengaruh terhadap ketuntasan belajar siswa.

Penyajian media terdiri dari beberapa halaman yakni halaman tampilan awal, halaman beranda menu, dan halaman isi ( $\mathrm{KD}$, tujuan pembelajaran, materi, quiz, referensi, profil pembuat dan petunjuk penggunaan media). Pada media pembelajaran ini siswa diberikan kebebasan dalam memilih materi pembelajaran yang diinginkan dan siswa dapat mengulang materi agar lebih paham. Materi koordinat kartesius yang disusun dalam 3 pertemuan yaitu pertemuan 1 berisi pengenalan koordinat kartesius; 
pertemuan 2 berisi kedudukan titik terhadap titik asal $(0,0)$ dan $(a, b)$; dan pertemuan 3 berisi kedudukan garis pada bidang kartesius. Pada halaman petunjuk penggunaan siswa dapat melihat petunjuk penggunaan media sehingga dapat menggunakan media pembelajaran dengan maksimal dan memudahkan dalam pengoperasian media pembelajaran.

Pada media pembelajaran ini juga dilengkapi dengan halaman quiz untuk menguji pemahaman siswa terhadap materi yang telah disajikan. Pada halaman quiz terdapat petunjuk pengerjaan quiz yang perlu diperhatikan oleh siswa. Kelebihan dari media pemebelajaran berbasis macromedia flash ini, yakni dilengkapi dengan latihan soal berupa quiz yang dapat dinilai langsung secara otomatis setelah siswa selesai mengerjakan.

Dalam mengembangkan media pembelajaran berbasis macromedia flash ini menggunakan model penelitian yang dikembangkan oleh Thiagarajan yang terdiri dari 4 yakni define, design, deveopement, dan dissemination (Masykur, 2017) Tahap pertama define yakni menganalisis segala kebutuhan yang diperlukan dalam mengembangkan media pembelajaran. Dari tahap ini didapatkan kompetensi dasar dan tujuan pembelajaran yang disesuaikan dengan kurikulum yang digunakan di SMP. Tahap kedua design yakni membuat rancangan media pembelajaran yang dibuat. Dari tahap ini didapatkan desain media pembelajaran yang dilengkapi dengan animasi visual yang mendukung siswa dalam pembelajaran materi koordinat kartesius. Tahap ketiga develope yakni terdiri dari pengerjaan media pembelajaran sesuai rancangan, validasi dari ahli dan uji coba kepada siswa. Tahapan keempat disseminate yakni penyebarluasan media pembelajaran. Penyebarluasan media ini dilakukan dengan pemberian software media pembelajaran kepada guru mata pelajaran matematika kelas VIII dalam bentuk CD.

Materi media pembelajaran berbasis macromedia flash ini telah disusun dengan baik dan sistematis ini ditunjukkan dari penilaian pada aspek materi (content) yang memiliki skor rata-rata 4,4 berkategori sangat baik. Berikut rincian per indikator dari ahli materi. (1) Kebenaran isi dan bebas dari kesalahan konsep memiliki skor rata-rata sebesar 4,3 berkategori "sangat baik", (2) Kebaharuan materi memiliki skor rata-rata sebesar 4,5 berkategori "sangat baik", dan (3) Kecukupan materi memiliki skor rata- 
rata sebesar 4,5 berkategori "sangat baik". Dari hasil tersebut menunjukkan bahwa materi koordinat kartesius kelas VIII yang ada dalam media pembelajaran macromedia flash telah valid. Hal ini sesuai dengan penelitian yang dilakukan oleh Azrianti (Azrianti, 2020) yang melakukan pengujian materi pada ahli materi untuk menghasilkan bahan ajar atau materi media pembelajaran yang berkategori berkategori sangat baik.

Berdasarkan hasil validasi ahli media, telah dihasilkan software media pembelajaran berbasis macromedia flash yang berkategori baik. Ini ditunjukkan dari hasil penilaian pada aspek media dan komunikasi pembelajaran yang memiliki skor rata-rata sebesar 4,0. Rincian per indikator dari ahli media sebagai berikut. (1) Kesesuaian pemanfaatan grafis visual memiliki rata-rata sebesar 4,0 berkategori "baik", (2) ketepatan penggunaan bahasa komunikasi memiliki skor rata-rata 3,8 berkategori "baik", (3) Tingkat interaktivitas dan kemudahan navigasi memiliki skor rata-rata 4,2 berkategori "baik", dan (4) Kemenarikan media memiliki skor rata-rata 4,0 berkategori "baik". Hal ini mengindikasikan bahwa media yang telah dikembangkan valid. Hasil penelitian tersebut sesuai dengan penelitian yang dilakukan oleh Salsabila (Salsabila, 2019) yang melakukan uji kevalidan media pembelajaran pada ahli media dengan kriteria valid.

Media pembelajaran telah diujicobakan kepada pengguna yakni siswa kelas VIII SMPN 19 Mataram. Menurut Nulhakim (Nulhakim, 2020) uji coba dapat dilakukan secara terbatas sesuai dengan situasi dan kondisi yang terjadi. Uji coba terbatas tersebut bertujuan untuk mengatahui penilaian aspek daya implementasi \& respons pengguna. Adapun hasilnya memperoleh kategori baik dengan skor rata-rata 4,0. Rincian per indikator dari respon siswa sebagai pengguna sebagai berikut. (1) Kemudahan dam kenyamanan penggunaan media memiliki skor rata-rata 4,0 berkategori "baik", (2) Tingkat minat dan motivasi siswa dalam belajar dengan media memiliki skor rata-rata 4,2 berkategori "baik", (3) Mendorong siswa berpikir kritis dan mandiri memiliki skor rata-rata 4,1 berkategori "baik" dan (4) Kemungkinan dapat digunakan sebagai alat bantu belajar secara individu mendapatkan skor rata-rata 3,8 berkategori "baik". Ini mengindikasikan bahwa software media pembelajaran berbasis macromedia flash materi koordinat kartesius ini baik dan layak digunakan sebagai alat bantu dalam belajar materi koordinat kartesius kelas VIII. 
Pengembangan media pembelajaran berbasis macromedia flash didasari adanya keterbatasan penggunaan media dalam proses pembelajaran di dalam kelas pada materi koordinat kartesius di SMPN 19 Mataram. Media pembelajaran yang sering digunakan dalam pembelajaran berupa papan tulis dan LKS. Media pembelajaran tersebut kurang menarik minat siswa dalam belajar karena format tulisan dan grafiknya monoton berwarna hitam. Media pembelajaran yang telah dikembangkan ini didesain untuk membantu pembelajaran offline di dalam kelas. Namun pada saat ini terjadi pandemi Covid-19 yang menyebabkan pembelajaran diharuskan dilakukan dari rumah. Pembelajaran materi koordinat kartesius dilakukan daring via Whatsap dengan pemberian modul pembelajaran dan tugas terstruktur kepada siswa.

Adapun kendala - kendala yang dialami dalam penelitian ini sebagai berikut:

1. Kendala dalam penelitian ini yakni perihal izin dari pihak sekolah dalam melakukan uji coba kepada siswa. Sekolah tidak mengizinkan uji coba dengan mendatangkan siswa dalam jumlah banyak ke sekolah sehingga diputuskan melakukan uji coba terbatas dengan siswa sebanyak 9 orang, Sembilan orang tersebut terdiri dari kelompok siswa dengan kemampuan rendah sebanyak 3 orang, siswa bekemampuan sedang 3 orang, dan siswa berkemampuan tinggi sebanyak 3 orang. Selain itu kendala berikutnya yakni izin penggunaan Lab. Komputer. Sekolah tidak dapat memberikan izin penggunaan Lab. Komputer karena pelaksanaan uji coba bertepatan dengan jadwal pengisian Raport elektronik, Lab.Komputer digunakan oleh para guru untuk menginput nilai dan data siswa. Untuk keperluan uji coba menggunakan laptop pribadi yang berjumlah 4 buah laptop. Akibatnya uji coba dilakukan dalam dua sesi menyesuaikan dengan jumlah laptop yang ada.

2. Kendala format media yaitu swf yang hanya dapat dioperasikan dengan menggunakan laptop atau komputer. Untuk menyesuaikan dengan pembelajaran di SMPN 19 yang banyak menggunakan smartphone saat pandemi Covid-19 maka formatnya dirubah menjadi MP4 atau html.

3. Kendala mengintegrasikan media pembelajaran ke dalam pembelajaran online di SMPN 19 Mataram. Agar dapat digunakan oleh siswa di rumah maka media pembelajaran harus dibagikan ke siswa. Media pembelajaran dapat dibagikan melalui Whatsap karena ukuran filenya kecil dan tidak memakan kuota internet yang cukup banyak untuk mendownload. 


\section{SIMPULAN}

Berdasarkan hasil penelitian, analisis data dan pembahasan, dapat disimpulkan bahwa produk yang dikembangkan telah memenuhi kriteria baik dan dapat dikatakan layak untuk digunakan sebagai alat bantu mengajar materi koordinat kartesius kelas VIII di SMP. Penyusunan materi dan pembuatan software media telah melalui tahap validasi ahli dan uji coba pengguna. Adapun penilaiannya dari aspek materi (content) dengan rata-rata 4,4 berkategori sangat baik, penilaian dari aspek media dan komunikasi pembelajaran dengan rata-rata 4,0 dengan kategori baik, penilaian dari aspek daya implementasi dan respons pengguna dengan rata-rata 4,0 berkategori baik..

\section{REFERENSI}

Andrisa. (2007). Student Guide Series Macromedia Flash 8. Jakarta: PT. Elex Media Komputindo.

Arsid, Irfan. (2020). Pengembangan Media Pembelajaran Matematika Mandiri Berbasis Macromedia Flash Materi Koordinat Cartesius. Elips: Jurnal Pendidikan Matematika, 1(1), 19-29.

Azrianti, V. A., \& Sukma. E. (2020). Pengembangan Media Pembelajaran Tematik

Chaeruman, U. A. (2015). Instrumen evaluasi media pembelajaran. Jakarta : Pusat Teknologi Informasi dan Komunikasi Pendidikan Kemendikbud.

Depdiknas. Peraturan Menteri Pendidikan Nasional No.23 tahun 2006 tentang Standar Kompetensi Lulusan. (2006). Jakarta: Depdiknas.

Depdiknas. Undang-Undang No.20 Tahun 2003 Tentang Sistem Pendidikan Nasional. (2003). Jakarta: Depdiknas.

Fanani, A. Z., \& Diginnovac. (2007). Bermain Logika ActionScript Macromedia Flash Pro 8. Jakarta: PT. Elex Media Komputindo.

Gunawan, M. A. (2015). Statistik Penelitian Bidang Pendidikan, Psikologi dan Sosial. Yogyakarta: Parama Publishing.

Hadipryitno, G., \& Makhrus, M. (2012). Pengembangan Media Pembelajaran Macromedia Flash Berorientasi Pembelajaran IPA Terpadu Tipe Connected. Jurnal PIJAR MIPA, 6(2), 42-49.

Hujair AH. Sanaky (2009) Media Pembelajaran. Yogyakarta: Safiria Insania Press

Jalinus, N., \& Ambiyar. (2016). Media dan Sumber Pembelajaran. Jakarta: Kencana.Jurnal Inovasi Pembelajaran SD, 8(4), 97-107.

Masykur, R., Nofrizal, N., \& Syazali, M. (2017). Pengembangan Media Pembelajaran Matematika dengan Macromedia Flash. Al-Jabar: Jurnal Pendidikan Matematika, 8(2), 177-186. Menggunakan Aplikasi Macromedia Flash untuk Menanamkan Karakter Positif.

Muhson, A. (2010). Pengembangan Media Pembelajaran Berbasis Teknologi Informasi. Jurnal Pendidikan Akuntansi Indonesia, 8 (2), 1-10.

Nulhakim, A. L. (2020). Pengembangan Media Pembelajaran Matematika Belajar Matematis Siswa SMA, Prosiding dari Seminar Nasional dan Teknologi Universitas Indraprasta (4), 361-366.

Prawiradilaga, D.S., Ariani, D., Dan Handodo, H. 2013.Mozaik Teknologi Pendidikan $\quad$ E Learning. Jakarta: Kencana.

Purwanto. (2011). Evaluasi Hasil Belajar. Yogyakarta : Pustaka Pelajar.

Rusman. (2012). Model-Model Pembelajaran : Mengembangkan Profesionalisme Guru. Jakarta : PT. Raja Grafindo Persada. 
Salsabila, N. H., \& Setyoningrum, W. (2019). Pengembangan Pengembangan Media Pembelajaran Matematika Berbasis Game: Statistics in Arctic. Mandalika Mathematics and Educations Journal, 1(1).

Sugiyono. (2017). Metode Penelitian Pendidikan. Bandung: Alfabeta.

Sutarti, T., \& Irawan, E. (2017). Kiat Sukses Meraih Hibah Penelitian. Yogyakarta:Deepublish.

Turmuzi, M. 2017. Strategi Pembelajaran Matematika. Mataram: Fakultas Keguruan dan Ilmu Pendidikan Universitas Mataram. 